\title{
Internet page content analysis of north European Sea ports
}

\author{
Olli-Pekka Hilmola ${ }^{1,2^{*}}$, Andres Tolli ${ }^{2}$ and Ain Kiisler ${ }^{2}$
}

\author{
* Correspondence: olli-pekka. \\ hilmola@lut.fi \\ ${ }^{1}$ Kouvola Unit, LUT University, \\ Prikaatintie 9, FIN-45100 Kouvola, \\ Finland \\ ${ }^{2}$ Tallinn University of Technology \\ (Taltech), Estonian Maritime \\ Academy, Kopli 101, 11712 Tallinn, \\ Estonia
}

\begin{abstract}
This study analyses 98 Internet pages of sea ports located in Sweden, Finland and Estonia during years 2017-2019. Aim of the study is to find, how website basic design is completed (colours and languages), how slogans, environmental issues, statistics and hinterland transports are reported. Based on the analysis, it appears as rather common that sea ports follow conservative selection of colours in their websites, where blue and white are clearly most popular. Typically, English and Swedish are as the most common used language, followed by Finnish, Russian and Estonian. In some rare cases, websites are offered in Chinese or German. Larger sea ports do have clear "slogans", where smaller ones are just having lengthy justification for their existence. Environmental issues are increasing concern among sea ports, and these are mostly mentioned in details within Swedish actors. Providing statistics varies among companies, and in some sea ports these are provided from very long time period, where in others from just previous years or then only from last year (or even at all). It is common for companies to report that they have sustainable hinterland access, railway available.

Keywords: Internet pages, Sea ports, Marketing, Strategy, Europe
\end{abstract}

\section{Introduction}

Currently two main contemporary trends in port logistics are related to digitalization and sustainability. Sea ports are becoming more digital in their operations, and these also concern traditionally paper based functions such as cargo movement authorizations from customs zones and payments of goods to suppliers (e.g. Tsiulin et al. 2020). Together with these is the development of corporate communication and image, which is in digital age associated with Internet appearance through own webpages (Pan and Xu 2009; Ageeva et al. 2019) and social media use (Ageeva et al. 2019). It could be said that many intangible image and successfulness of corporate communication are dependent how much information is being provided, what types of information is available and how fresh information actually is. It should be reminded that Internet websites of corporations are part of communications strategy, and portray it (García et al. 2017). Andrikopoulos et al. (2013) found that in international shipping industry size, profitability, leverage and ownership structure influence on the range of publicly available Internet page information. Similarly, sustainability (concerning dimensions of social, environment and economy) has become important issue to be dealt and properly communicated in logistics and supply chains (Dey et al. 2011; Fahimnia

(c) The Author(s). 2020 Open Access This article is licensed under a Creative Commons Attribution 4.0 International License, which permits use, sharing, adaptation, distribution and reproduction in any medium or format, as long as you give appropriate credit to the original author(s) and the source, provide a link to the Creative Commons licence, and indicate if changes were made. The images or other third party material in this article are included in the article's Creative Commons licence, unless indicated otherwise in a credit line to the material. If material is not included in the article's Creative Commons licence and your intended use is not permitted by statutory regulation or exceeds the permitted use, you will need to obtain permission directly from the copyright holder. To view a copy of this licence, visit http://creativecommons.org/licenses/by/4.0/. 
et al. 2015). One sub-branch of sustainability is green marketing (Papadas et al. 2017), and both of these could be examined through strategic, tactic and operational level (Papadas et al. 2017; Lam and Li 2019). Sea ports play key role in here as most of the world trade's material flows are executed through sea transports. Lam and Li (2019) concluded that larger sea ports in Europe have performed better in this regard as compared to Asia. However, Europe is much more in sea port related logistics than what only largest sea ports represent. Europe is complex structure of numerous different countries with coastal line, and each sea connected country having numerous sea ports at their disposal. In comparison to USA, amount of sea ports is much higher and use of trucks in hinterland transports more in common (Vassallo 2005; Stamos 2018; Hilmola 2019).

This research concerns sea ports of three smaller North European countries, namely Sweden (population 10.1 mill.), Finland (population 5.5 mill.) and Estonia (1.3 mill.). All of these countries have coastal line, and are mostly surrounded by Baltic Sea (western part of Sweden belongs to North Sea). Although, these countries are small in population terms, they have significant amount of sea ports available for foreign trade transports. In Sweden (Trafa 2017) and Finland (Statistics Finland 2019), total amount of foreign trade sea ports is 45-50 in both countries (and half of them are open throughout the year), while in Estonia foreign trade sea port amount (Estonian Ports Association 2019) reaches nearly 30 (and major sea ports of them are six). Of course, foreign trade is in each country within hands of very few sea ports (Pareto distributed volumes in different cargo groups), but activity reaches numerous different sea ports and actors. Typically, sea ports are owned by local government or state, and they are important parts of budgetary income. Therefore, their businesses are run rather professionally, and public appearance receives similar attention like any private sector company. Sea ports are typically serving number of different stakeholders as e.g. landlord port model is very common. Therefore, communication through websites is not only important for interested sea port using customers (cargo owners), passengers, shipping companies, hinterland transportation companies or common audience, but similarly important for logistics operators, warehouse owners in sea port area and different types of contractors. This gives motivation for our research work through following questions: How most important public information channel, Internet websites, are used in sea port communication? What is the role of used languages, colours and environmental sustainability? Is website design and marketing communications similar among sea ports or could we find some best practices among analyzed sea ports? We try to dive deeper in the analysis of sea ports, similarly with used disclosure indexes, which have been applied in the classification of some part(s) or entire Internet websites of corporations (Andrikopoulos et al. 2013; Ahmed et al. 2015; Garay et al. 2013). In the following analysis we do not argue to find single "best practice" website from sea ports, however, from each analyzed sub-area are mentioned interesting sea ports, which could give ideas for further development of Internet appearance.

This research is structured as follows: In Section 2 corporate and company based communication through Internet and webpages is analyzed through earlier research. Thereafter, in Section 3 research methodology and data collection is described for Estonian, Finnish and Swedish sea ports. In Section 4, we analyze the results, and concentrate mostly on used colours, offered languages, slogans, availability of statistics and environmental sustainability. Research work is concluded in Section 5, where we also provide avenues for further research. 


\section{Literature review: corporate communication through internet}

The use of Internet in corporate communication differ between companies and countries. For example, Pan and Xu (2009) showed with empirical data of 150 corporate webpages (75 from USA and 75 from China) that cultural value explain quite much company based differences. In USA there was identified more interaction between company and its customers, while in China there were common discussion groups among customers (later on importance of social media on Chinese consumers have been analyzed to be greater than that of USA; Chu et al. 2020). Already in Pan and Xu (2009) research work there were findings based on analysis that USA based companies were showing sustainability results more, and this not only from environmental perspective, but also social (although in corporate social responsibility Chinese companies have identified Internet websites as important information channel together with local media; Wang and Chaudhri 2009). Empirical survey research works from UK and Russia (Ageeva et al. 2019) as well as Iran (Rahimnia and Hassanzadeh 2013) highlight that Internet webpages are important source of trust and marketing effectiveness, and eventually using company's services and/or products. It is important not only to provide some information, but actually the range of information should also be considered - Andrikopoulos et al. (2013) used 31 different evaluated items in investor information of shipping companies within company websites. In year 2010, only very few shipping companies were providing financial data in spreadsheets (e.g. for further analyses), online appearance, changes of stockholders equity in the analyzed year and earnings forecasts (Andrikopoulos et al. 2013). Range of provided information from company at websites is not only associated to internal profitability performance of company, but also to that of market value (Ahmed et al. 2015; Garay et al. 2013).

Lam and Li (2019) used more advanced approach as examining websites and annual reports of leading container sea ports in the world as they tried to find whether sea ports implemented sustainability in three different levels (strategies, structures and functions). Again, cultural or geographical difference was apparent. European and USA based sea ports were more widely taking sustainability seriously, while sea ports in Asia, and especially emerging Asia, were more focused on traditional performance of sea port (like volumes, investments, trade and industries). However, there also exist sea ports in Asia performing similarly with European or USA ports, but they are few (like Singapore, Hong Kong, Port Klang, and Tanjung). Depth of sustainability reminds quite much green marketing, where Papadas et al. (2017) found many levels and dimensions of this approach, and it is clear that not every company fulfills these aspects, but they are rather "green washing" their products or services with isolated actions of green marketing. Similarly, Kokkila and Ojala (2019) found that in Northern European sea port websites, especially from safety and security aspects, there existed a lot of variance, and typically best websites were located in Finland, Estonia or UK. Lowest performance in this regard was found from smaller sea ports of Denmark, Sweden, Germany and Norway.

\section{Research methodology}

Empirical material was gathered in the fourth year B.Sc. program course called "Maritime Marketing" (in native language, "Meretranspordi turundus") at Taltech within Estonian Maritime Academy (EMERA). Course is one of the last courses before students start to write their B.Sc. theses, and it is given in autumn term. It consists regular lectures by faculty members, but also numerous visiting lectures from industry (such as 
shipping company and sea ports). During the course, students are asked to analyze webpages of sea ports from Estonia and near-by countries, such as Finland and Sweden. In the first year (2017), students only concentrated on Finland and Sweden, but sea port list was expanded to concern Estonia too in the following years (2018-2019). Data gathering list for students has remained pretty much the same during the year, only environmental and market growth were added in latter 2 years. Readers may access assignment letter to students in Appendix. Students have several weeks' time to complete website analysis (either one or two sea ports), and data is gathered together by instructor (in spreadsheet based database). Results are discussed in $1.5 \mathrm{~h}$ long lecture in order to verify results, and also most importantly, to learn from the overall results, and that students are able to see, how results differ between countries and different sized sea ports.

During the years database of different sea ports being analyzed has reached 98 . From year 2017 database consists 38 sea ports, and years 2018 and 2019 have both 30 sea ports included. Some sea ports are twice or even three times in database as different years are taken as different webpage (or observation). In database is included 51 different sea ports, but overall website analyses consists 98 sea ports. On the average, sea port is 1.92 times in the analysis. Gathered data could be considered as reliable as given data from students is in random fashion checked by instructor (as entering results to database), many students provide screenshots and text from data gathering and results are discussed in separate lecture.

It is rather common to include second hand sources, like websites, on the scientific research works. However, in many cases websites are analyzed using disclosure indexes (e.g. Andrikopoulos et al. 2013; Ahmed et al. 2015; Garay et al. 2013), where these sites are analyzed based on the list of factors / information sources being checked from company website, and to gain information whether they are available or not (binary). Indices are then calculated from these gathered binary databases for each company. Approach used in this research is similar to Lam and Li (2019), research which examined 30 largest container sea ports from the world using websites, annual reports and sustainability reports. However, our examination is limited only to websites.

\section{Research results}

Rather interestingly, all three countries and their sea ports are rather similar and same time conservative in the use of website colours (Fig. 1). As in Northern Europe winter is present for four months, it is understandable that white is rather popular colour together with blue (colour of sea). Mentioned two colours are also present in the national flags of these three examined countries (both colours in Estonia and Finland, while blue in the case of Sweden). If black and green are also included, these colours take share of 84.4\% from used colours during the years in Fig. 1. Of course, colours are used together and in combination within websites, so students were gathering information from one to three most important colours used (and these are all treated equal in Fig. 1 frequency calculations). Typical blue-white website design in year 2019 could be accessed by visiting sea port webpages of Port of Gävle (2019a) and Port of Tallinn (2019). In some sea ports, blue-white combination dominates, but there is clearly third colour used, like red (e.g. Port of Hanko 2019) or green (e.g. Port of Naantali 2019). However, some interesting trials with other rarely colours exist, like that of Port of Oulu (2019), which combines black-white-yellow together in rather workable and attractive fashion. 


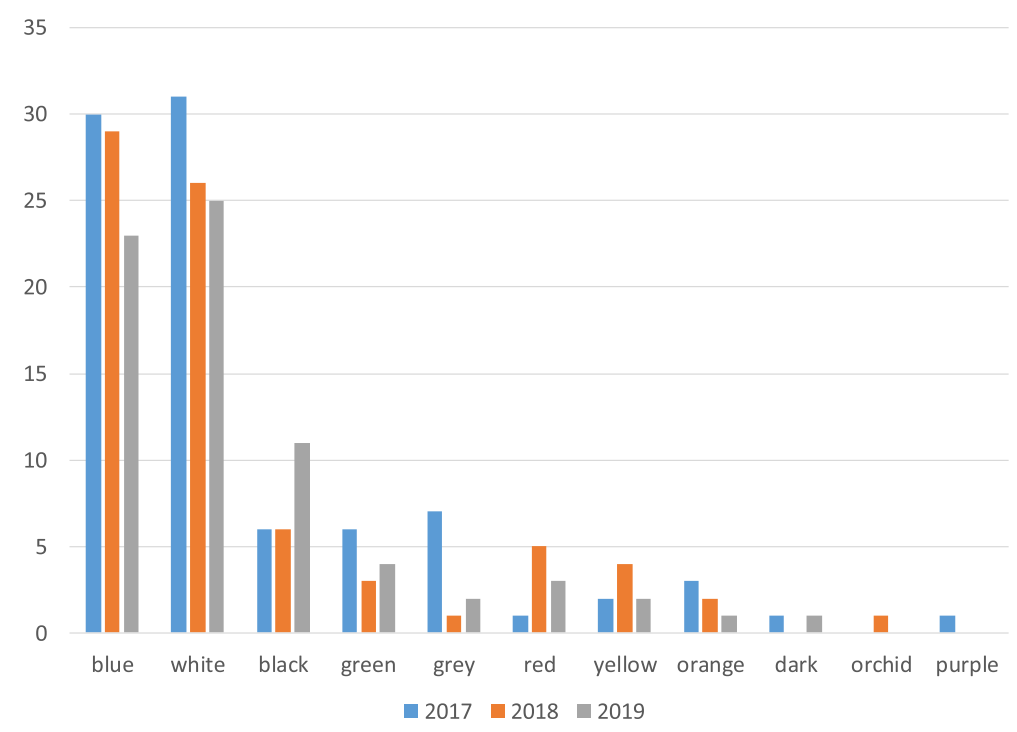

Fig. 1 Sea port website colours used in analyzed countries

It is understandable that English is leading in language options of sea ports (Fig. 2), however, what is surprising, is the importance of Swedish as the second most popular language. This latter could be explained by two factors, and one of them is that in database numerous Swedish sea ports are included. Secondly, Swedish is still second official language of Finland (as country belonged to Swedish empire several hundred years ago). If Finnish, Russian and Estonian are included in the website languages, these five languages cover $95 \%$ from offered languages. What is interesting in these results, is the rather low frequency of Russia and having only one website offering Chinese or German. In the end, during the previous decades Russian and eastern market (using Russian or relative languages) has been dominating the growth of physical goods movement at the region, and sea port handling and sea transports. Russian option is offered mostly by Estonian and Finnish sea ports. It is also similarly striking that Chinese is offered only in one website (Port of Gothenburg 2019a), although China is dominating world's manufacturing

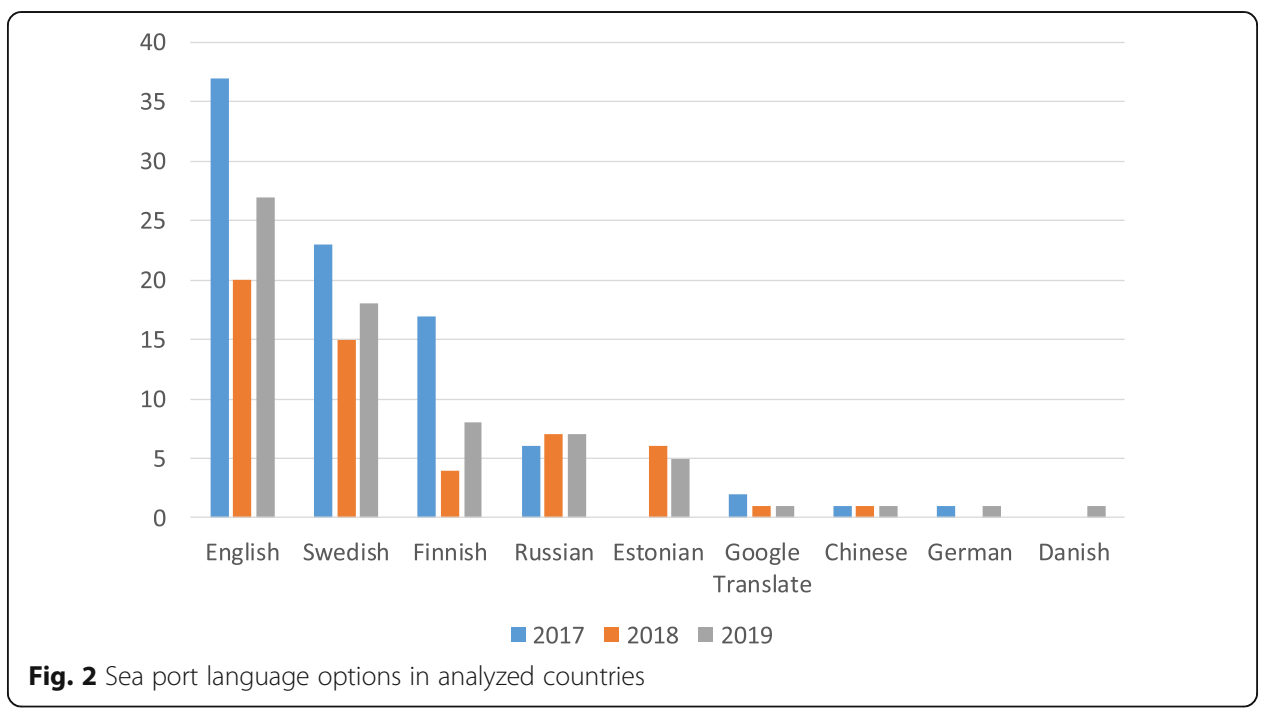


related supply chains and is most often the origin or destination of maritime supply chains. Germany is strongest European country in foreign trade, but it is having only one small Swedish sea port offering German language (Port of Söderhamns 2019).

In some sea ports (smaller ones such as Port of Ystad 2019 and Port of Lysekils 2019), website language is only given in native language, however, there is an option to use Google Translate for over 100 languages. This is of course cost efficient and versatile option for sea port to offer information for potential customers around the world. In each year, this option has been discussed with students, and translations are tried to e.g. Estonian (from original, Swedish). Typically, this is considered as acceptable, however, quality of language is still not that high or even moderate (some translations are not workable at all), and it is not an option for business having higher volumes and that need to have high quality image. This does not mean that using online translator would not have future - language technology and artificial intelligence are developing all the time further and better.

Websites typically do not offer that good port statistics or basically statistics at all (72.4\%), however, there are still some sea ports, which do oppositely (Fig. 3). Longest data access is currently available through Port of Gothenburg (2019), where some statistics date back to 1960's (e.g. container handling). Port of Gothenburg (2019b) statistical section is also interesting in a way that it provides comparison to entire Sweden too (ports). Other sea ports providing longitudinal perspective are Port of Helsingborg (2019), which has data present from 1998 onwards, and Port of Rauma (2019) showing statistics since 1991.

Many of analyzed sea ports do not have any "slogan" on their website or then slogan is long sentence(s), which do not justify the definition of "slogan" in marketing. They are rather repeating information regarding geographical position and/or most important cargo groups or customers. However, some sea ports have truly developed "slogans" as can be seen in Fig. 4. Maybe most unique slogans among analyzed are following: "because time matters" (Port of Turku 2019), "welcome from land and sea" (Port of Uusikaupunki 2019), "fast and friendly port" (Port of Hanko 2019) and "the port of good news" (Port of Tallinn 2019).

In website analyses of 2018 and 2019 were data gathered from environmental sustainability of sea ports, and also concerning whether sea ports mention about railway option and/or its infrastructure availability. Many smaller sea ports do not have any

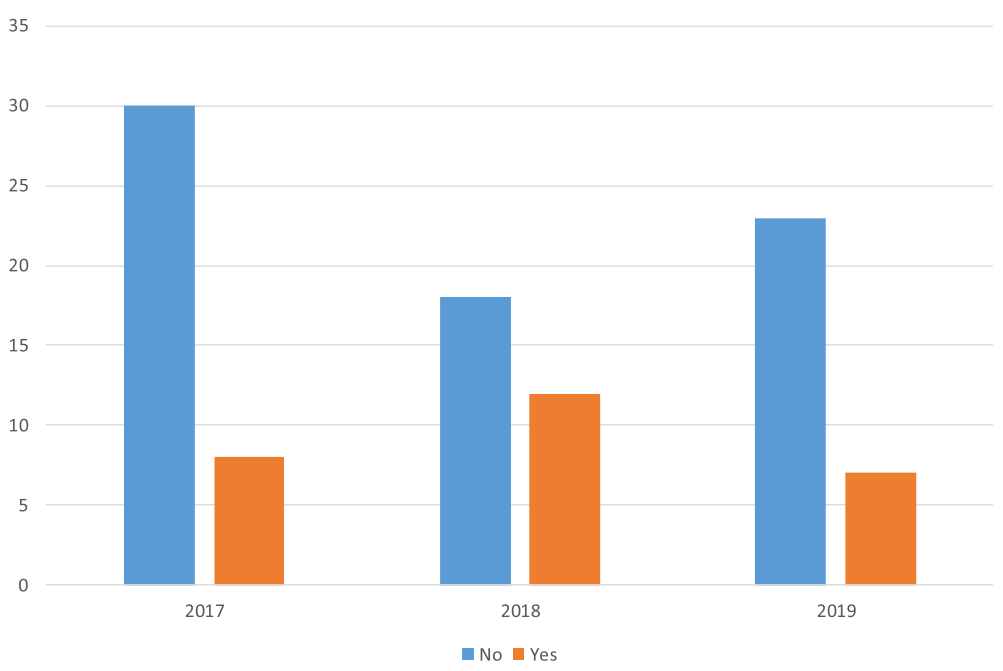

Fig. 3 Sea port statistics offered in analyzed countries 
The port never sleeps

Because time matters

The hub of east coast

The port of good news

$$
\text { Strongly and Sharply }
$$

The biggest universal port in Finland
A safe heaven

Fast and Friendly Port

\section{Welcome from land and sea}

Fig. 4 Selected slogans used by sea ports in three examined countries

sections regarding environment or their environmental policies. Some sea ports see activity from single point of view, like constantly checking water quality. Nearly all bigger sea ports do have separate sections for environment, but typically they are general descriptions. It is rather interesting to find out that one-third of sea ports do not even mention environmental sustainability - nearly equal amount of sea ports do not have railway option or they do not communicate that through webpages (see Fig. 5). However, in further analysis it was found that some Swedish sea ports, like Port of Trelleborg (2019) and Copenhagen Malmö Port (2019) do have detailed descriptions together with actions taken from multiple point of views concerning environment (e.g. including air, water, soil, energy, noise, material flow and membership of EcoPorts foundation). Although, environmental information is missing in websites, it is rather common for sea ports to report about their environmentally friendly hinterland transportation modes, like significant railway infrastructure existing in Port of Sillamäe (2019) or having conductive electrical charging lines for trucks available for testing nearby Port of Gävle (2019b). In general, environmental sustainability reporting and appearance in analyzed sea ports is not consistent, and it is from nothing to operational, tactical or strategical (or all three last mentioned in the best cases).

We also did analyze the use of colours in environmental sustainability mentioning sea ports, and could not find any larger use of "green" colour. In 2018 green colour was used in three port webpages, and two of them did not have any information concerning environmental sustainability. In 2019 situation was rather similar as four webpages in

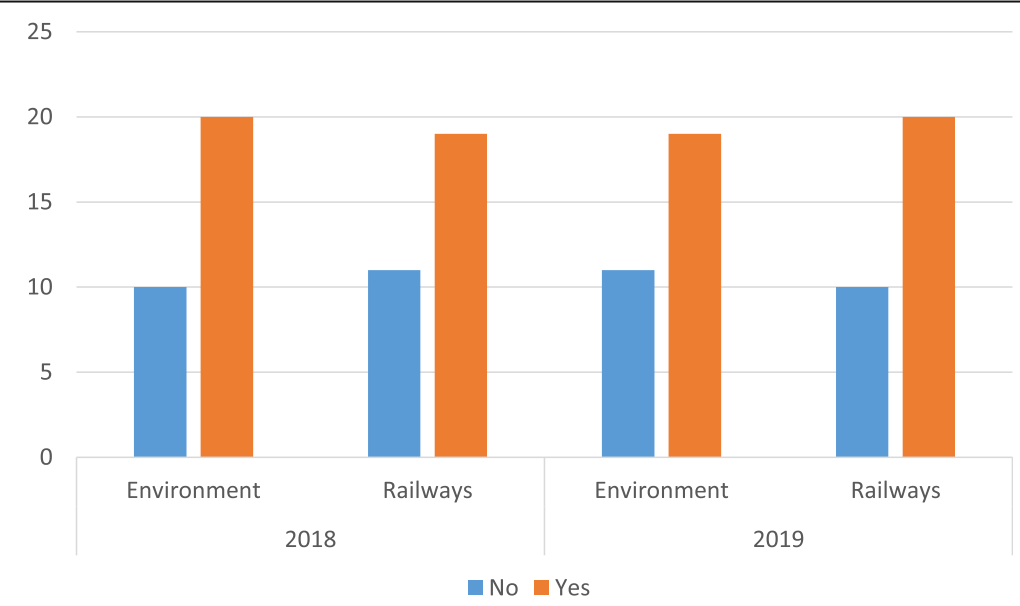

Fig. 5 Environmental sustainability or railways mentioned in sea port webpages of analyzed countries 
total used green colour, and two of them were not mentioning environmental sustainability. As green colour used could also be often affiliated in the railway hinterland option (as it is emitting much less as compared to trucks), it was also further analyzed in 2018 and 2019. In both years three out of four port webpages using green colour were mentioning railway option somehow in their webpages.

\section{Conclusions}

Completed analyses revealed that websites of sea ports in Northern Europe are rather conservative, and typically are targeted for the purposes of local economy. Larger sea ports in the analyzed area are of course following more closely international communication and marketing standards, but very few were exceptional e.g. in providing statistics or environmental sustainability information. In the earlier research lack of statistics and in-depth financial information has been argued to be a part of less successful shipping companies (Andrikopoulos et al. 2013), and environmental sustainability in many occasions only part of activity called green washing (Papadas et al. 2017). In analyzed countries there is some activity for even public listing of sea ports to stock exchanges, and in the light of earlier research availability of statistics and financial information is seen as a vital part of shareholder value creation (Ahmed et al. 2015; Garay et al. 2013).

It was also found that few language options were available at sea port websites, and this does not indicate that prosperous future for international trade facilitation and growth. In earlier research (Ageeva et al. 2019; Rahimnia and Hassanzadeh 2013; Pan and Xu 2009), Internet page functionality and service availability has been important part of successful use and communication of corporate information whatever the culture and country is. In addition, colours used of webpages were rather similar, only having few exceptions. Green colour (denoting environmental sustainability) use was very rare, and it was not only caused by environmental sustainability reporting at webpages, but merely by the availability of railway transportation option. Many sea ports do not have marketing slogans used at all, however, there were some very good ones as shown in empirical part. These all indicate that North European sea ports have route to proceed further in marketing, and within the most important channel, Internet. Situation is not necessarily as good as was argued it to be within largest container sea ports of Europe (Lam and Li 2019). It could also be so that national and branch culture constrain marketing development (like concluded in Pan and $\mathrm{Xu}$ 2009). Maybe best benchmark for sea ports could be banking sector, which was prior to Internet era as conservative as sea ports. However, now it is leading in the use of IT through Internet (Ageeva et al. 2019), and conventional "brick-and-mortar" banking is disappearing. In general, around one third of analyzed sea port webpages mention environmental sustainability or railway transportation mode availability. However, there was no indication of "green washing" (Papadas et al. 2017) as in many cases e.g. environmental sustainability was in rather minor role or its role was understood as very limited.

One natural further step to continue this research would be to conduct website analyses further in following years. To get proper "big picture", it would be interesting to include also other Baltic Sea countries in the analysis, like Russia, Latvia, Lithuania, Poland, Germany and Denmark. Especially interesting it would be to analyze sea ports, which have experienced significant growth in the previous two decades within international trade movements, like handling of containers (Russia's St. Petersburg sea port and Polish Gdansk as well as Klaipeda of Lithuania). 


\section{Maritime Marketing Website Analysis Assignment Form}

\section{Sea Ports in Estonia, Finland and Sweden - Website Marketing Analysis}

In the below exist links to webpages of most of the Estonian, Finnish, and Swedish sea ports. Please distribute this task with students so that all sea ports are analyzed regarding websites and their marketing message delivery. Some students will then analyze two sea ports, while others only one. It is your task to distribute this task to the students of Maritime Marketing course.

When, what and how?

\section{Delivery date of analysis: 11.Nov.2019 (Monday, 8 pm)}

Please analyze sea port webpages based on following marketing characteristics:

- Colours used in the webpage

- Do you consider this webpage as modern and good one (designed to be used also with mobile phones and tablets or just for PCs)?

- Language options of website

- Main slogan/message of the port (what they are using to market this very location)

- How environmental issues (or sustainability, which contains environmental aspects) are taken into account (communicated)?

- Do webpages mention something about China (or Chinese customers)? Or does it mention something about eastern markets (like Russia, Belarus, Ukraine etc.)? Or is port connecting point to Central Europe or Scandinavia?

- Do webpages mention something about growth (e.g. freight or passenger group growing)?

- Is webpage distinct or is it part of webpages of some community/town or company?

- Access of port statistics (is it available at all?)

- Access to technical data of sea port (depth, amount of docks, lifting capacity, terminal areas, access to road and rail etc.)

- Are regular shipping connections somehow mentioned (schedule or even live schedule)?

- Are terminals and operating companies mentioned?

- Is railway infrastructure mentioned?

Please write one page (min.) memo from above characteristics from sea port analyzed. Please return this analysis of one (or in case of some students, two) sea ports to instructors email.

We shall discuss about the findings of this analysis in the latter part of Nov.2019 within lecture. Thank you.

Acknowledgements

We would like to express our gratitude for fourth year B.Sc. students of Taltech within Estonian Maritime Academy (EMERA) during years of 2017-2019 of helping to gather this used data.

\section{About the authors}

PhD Olli-Pekka Hilmola is working as a Professor in LUT University, in Kouvola, Finland. He is affiliated with numerous int. journals through editorial boards, including Industrial Management and Data Systems, Decision Support Systems, and Expert Systems with Applications. Dr. Hilmola has published around 170 refereed journal manuscripts. He is currently serving as Visiting Professor in Taltech/EMERA, Estonia.

Andres Tolli is an Associate Professor at the Tallinn University of Technology, Estonian Maritime Academy in Tallinn, Estonia. He also acts as the Head of Centre for Maritime Studies. He is an experienced logistics professional with a history of consistent success driving the planning and execution of mission-critical projects and services across a range of industries. 
Ain Kiisler is a Lecturer in Estonian Maritime Academy at Tallinn University of Technology in Tallinn, Estonia. He also acts as the Head of Unit for Maritime Studies. He works as a logistics consultant and trainer.

\section{Authors' contributions}

Main author of this research is Olli-Pekka Hilmola, who is responsible for the data gathering during the years, and writing of first draft. Thereafter, two other authors have commented improved and modified manuscript as well as analysis. Data gathering has taken place in Maritime Marketing course, which has been overall organized by Andres Tolli. The authors read and approved the final manuscript.

\section{Funding}

This research did not enjoy any particular grant, but it was done during annual working hours of university for basic / applied research.

\section{Availability of data and materials}

Used empirical data of this research is available from corresponding author by request (e-mail).

\section{Competing interests}

There does not exist any competing interest among authors of this manuscript.

Received: 4 June 2020 Accepted: 16 September 2020

Published online: 02 October 2020

\section{References}

Ageeva E, Melewar TC, Foroudi P, Dennis C (2019) Cues adopted by consumers in examining corporate website favorability: an empirical study of financial institutions in the UK and Russia. J Bus Res 98:15-32

Ahmed AH, Tahat YA, Burton BM, Dunne TM (2015) The value relevance of corporate internet reporting: the case of Egypt. Advances in Accounting, incorporating Advances in Internal Accounting 31(2):188-196

Andrikopoulos A, Merika AA, Triantafyllou A, Merikas AG (2013) Internet disclosure and corporate performance: a case study of the international shipping industry. Transp Res A 47:141-152

Chu S-C, Chen H-T, Gan C (2020) Consumers' engagement with corporate social responsibility (CSR) communication in social media: evidence from China and the United States. J Bus Res 110:260-271

Copenhagen Malmö Port (2019) Environmental section of website Available at URL: http://www.cmport.com/corporate/ environment Retrieved: Nov.2019

Dey A, LaGuardia P, Srinivasan M (2011) Building sustainability in logistics operations: a research agenda. Manag Res Rev 34(11):1237-1259

Estonian Ports Association (2019) Estonian ports association webpage, member ports Available at URL: https://www. estonianports.com/ports/ Retrieved: Dec.2019

Fahimnia B, Sarkis J, Davarzani H (2015) Green supply chain management: a review and bibliometric analysis. Int J Prod Econ 162:101-114

Garay U, González M, Guzmán A, Trujillo MA (2013) Internet-based corporate disclosure and market value: evidence from Latin America. Emerg Mark Rev 17:150-168

García MG, Carrillo-Durán MV, Jimenez JLT (2017) Online corporate communications: website usability and content. J Commun Manag 21(2):140-154

Hilmola O-P (2019) The Sulphur cap in maritime supply chains: environmental regulations in European logistics. Palgrave Macmillan, Pivot Series, London UK

Kokkila S, Ojala L (2019) North European port authorities' website content and usability evaluation Hazard, Final Conference (15.March.2019). Available at URL: https://blogit.utu.fi/hazard/wp-content/uploads/sites/65/2019/03/9_HAZARD-FC_SariKokkila-Lauri-Ojala.pdf Retrieved: 30.12.2019

Lam JSL, Li KX (2019) Green port marketing for sustainable growth and development. Transp Policy 84:73-81

Pan P-L, Xu J (2009) Online strategic communication: a cross-cultural analysis of U.S. and Chinese corporate websites. Public Relat Rev 35:251-253

Papadas K-K, Avlonitis GJ, Carrigan M (2017) Green marketing orientation: conceptualization, scale development and validation. J Bus Res 80:236-246

Port of Gävle (2019a) Website of port of Gävle Available at URL: www.gavlehamn.se Retrieved: Nov.2019

Port of Gävle (2019b) Environmental section of website Available at URL: https://gavlehamn.se/EN/environment-and-safety Retrieved: Nov.2019

Port of Gothenburg (2019a) Website of port of Gothenburg Available at URL: www.portofgothenburg.com Retrieved: Nov. 2019

Port of Gothenburg (2019b) Statistics section of port of Gothenburg Available at URL: https://www.portofgothenburg.com/ about-the-port/ports-of-the-world-in-figures/ Retrieved: Nov.2019

Port of Hanko (2019) Website of port of Hanko Available at URL: www.portofhanko.fi Retrieved: Nov.2019

Port of Helsingborg (2019). Statistics section of Port of Helsingborg. Available at URL: http://www.port.helsingborg.se/foretag/ gods-och-trafik/godsstatistik/ Retrieved: Nov.2019

Port of Lysekils (2019) Website of port of Lysekils Available at URL: http://www.lysport.se/ Retrieved: Nov.2019

Port of Naantali (2019). Website of port of Naantali. Available at URL: www.portofnaantali.fi Retrieved: Nov.2019

Port of Oulu (2019) Website of port of Oulu Available at URL: www.ouluport.com Retrieved: Nov.2019

Port of Rauma (2019) Statistics section of port of Rauma Available at URL: http://www.portofrauma.com/sites/default/files/ rauman_satama_liikennetilastot_1991-2017_.pdf Retrieved: Nov.2019

Port of Sillamäe (2019) Railway section of website Available at URL: http://wwwsilportee/about-railwaystationhtml Retrieved: Nov.2019

Port of Söderhamns (2019) Website of Söderhamns Stuveri \& Hamn AB Available at URL: wwwsshabcom Retrieved: Nov.2019 
Port of Tallinn (2019) Website of port of Tallinn Available at URL: wwwportoftallinncom Retrieved: Nov.2019

Port of Trelleborg (2019) Environmental section of website Available at URL: https://www.trelleborgshamn.se/en/english/ about-the-port/environment/environmental-programme/ Retrieved: Nov.2019

Port of Turku (2019) Website of port of Turku Available at URL: https://www.portofturku.fi/en/ Retrieved: Nov.2019

Port of Uusikaupunki (2019) Website of port of Uusikaupunki Available at URL: http://www.ukiport.fi/ Retrieved: Nov.2019

Port of Ystad (2019) Website of port of Ystad Available at URL: http://wwwystadse/port Retrieved: Nov.2019

Rahimnia F, Hassanzadeh JF (2013) The impact of website content dimension and e-trust on e-marketing effectiveness: the case of Iranian commercial saffron corporations. Inf Manage 50:240-247

Stamos I (2018) What do data tell us? The story of the European logistics and road freight transportation sector. Proceedings of 7th Transport Research Arena TRA 2018, April 16-19, 2018, Vienna

Statistics Finland (2019) International Sea transport by port and commodity group 2000-2019 Available at URL: http://pxnet2 stat.fi/PXWeb/pxweb/en/StatFin/StatFin_lii__uvliik/statfin_uvliik_pxt_001.px/ Retrieved: Dec.2019

Trafa (2017) Shipping Goods 2016. Trafik analysis, Statistik 2017:19, Stockholm

Tsiulin S, Reinau KH, Hilmola O-P, Goryaev N (2020) Blockchain in maritime port management: defining key conceptual framework. Rev Int Bus Strategy 30(2):201-224

Vassallo JM (2005) Nature or nurture: why do railroads carry greater freight share in the United States than in Europe? Research working paper series, WP05-15. Harvard University, USA

Wang J, Chaudhri V (2009) Corporate social responsibility engagement and communication by Chinese companies. Public Relat Rev 35:247-250

\section{Publisher's Note}

Springer Nature remains neutral with regard to jurisdictional claims in published maps and institutional affiliations.

\section{Submit your manuscript to a SpringerOpen ${ }^{\circ}$ journal and benefit from:}

- Convenient online submission

- Rigorous peer review

- Open access: articles freely available online

- High visibility within the field

- Retaining the copyright to your article

Submit your next manuscript at $\boldsymbol{\nabla}$ springeropen.com 